\title{
Transformasi Pitch Suara Manusia Menggunakan Metode PSOLA
}

\section{SUSETYO BAGAS BHASKOROㄹ, I RNA ARI ANI ${ }^{2}$, ANANDHA A. ALAMSYAH ${ }^{3}$}

1. Prodi Teknik Informatika Universitas Widyatama

2. Teknik Media Digital dan Game Institut Teknologi Bandung

3. Institut Teknologi Sepuluh Nopember Surabaya

Email:susetyo.bagas@widyatama.ac.id

\begin{abstract}
ABSTRAK
Kemampuan pengubahan suara yang dilakukan Dubber untuk beragam bentuk suara menjadi perhatian khusus dengan melakukan rekayasa suara, di dalam perkembangan teknologi di kenal sebuah teknikpitch shifting yang digunakan untuk mengubah suara manusia di bagian timbre dan pitch. Penelitian ini menggunakan metodepitch shifting PSOLA (Pitch Synchronous Overlap Add) untuk merubah pitch sekaligus timbre suara. Proses yang dilakukan meliputi perekaman suara sehingga didapatkan sinyal suara. Sinyal hasil perekaman kemudian diolah untuk menemukan posisi pitch dari sinyal pada domain waktu. Setelah posisi pitch diketahui, jarak antar pitch akan dikalikan dengan bilangan skala pergeseran yang sudah ditentukan. Hasil dari perkalian tersebut adalah perubahan pada pitch suara, sehingga menghasilkan suara yang lebih tinggi atau lebih rendah. Perubahan juga terjadi pada timbre sehingga menghasilkan karakter suara yang berbeda dengan suara aselinya. Hasil pengujian pitch dan timbre dengan menggunakan metode PSOLA menunjukkan keberhasilan mencapai 98\% berdasarkan sinyal sinus.
\end{abstract}

Kata kunci: Pitch, Timbre, Pitch Shifting, PSOLA.

\begin{abstract}
The ability of converts sound done in various forms of a dubber sound, becomes a special attention in doing an engineering design sound. In the development of technology the pitch of shifting know a technique that is used to turn the human voice in the timbre and pitch. This study using methods pitch shifting psola (pitch synchronous overlap add) to change the pitch as well as the timbre sound. The process was about recording a sound so obtained up a noise. Recording signals then processed the results to find the position of the pitch signals on the domain of time. After the position of the pitch known, the distance between the pitch will be multiplied by the number of the scale of a shift that had been determined. The result of the multiplication of the sound is a change in pitch, so producing a higher or lower, Also happens to change the timbre that produces characters a different voice with the original sound. The examination result of pitch and timbre using PSOLA method shows the success as big as $98 \%$ for signal sinus examination.
\end{abstract}

Keywords: Pitch, Timbre, Pitch Shifting, PSOLA. 


\section{PENDAHULUAN}

Perkembangan teknologi multimedia menjadikan film animasi berkembang dengan pesat.Saat ini terdapat beragam film animasi yang dijadikan media hiburan sampai dengan media pembelajaranyang terbagi menjadi berbagai kategori umur.Karakteristik yang dimiliki oleh film animasi biasanya gambar, karakter figur, alur cerita dan suara.Suara di dalam film animasi dilakukan oleh seorang Dubber untuk menggambarkan emosional karakter figur dalam berkomunikasidengan lawan bicaranya di sebuah alur cerita(Bhaskoro, 2013). Seorang Dubber biasanya memiliki peran yang beragam sehingga di dalam menghasilkan karakter suara juga harus beragam.

Sebagai contohnya seorang Dubber memiliki peran untuk mengisi suara karakter figur dengan suara yang normal artinya suara yang digunakan oleh seorang Dubber adalah suara aseli yang tidak ada perubahan. Namun situasi dapat berbeda jika seorang Dubbermemiliki peran yang berbeda dengan karakteristik suara aselinya maka fungsi seorang Dubber adalah menyamarkan suara aselinya dengan menaikkan maupun menurunkan pitch dan timbre. Aktifitas untuk mempertahankan konsistensi pitch dan timbre dalam ukuran tertentu merupakan hal yang sulit dilakukan oleh manusia.Oleh karena itu teknologi dibutuhkan untuk membantu konsistensi keluaran suara dalam ukuran pitch dan timbre tertentu.

Proses untuk mengubah karakteristik suara manusia bergantung dari kemampuan untuk mengontrol sistem organ penghasil suara manusia diantaranya mulut dan rongga hidung serta kemampuan pernafasan manusia. Manusia yang mampu mengontrol sistem organ suara akan dapat menghasilkan suara yang berbeda. Ganguan pada sistem pernafasan seperti hidung tersumbat juga dapat mengubah suara yang dihasilkan manusia walaupun hal tersebut mungkin tidak diinginkan atau disengaja (Patton, 2014).

Melalui perkembangan teknologi informasi saat ini, proses pengubahan suara manusia dapat dilakukan melalui proses komputasi. Namun untuk melakukan perubahan suara dibutuhkan sebuah aplikasi yang dikembangkan secara khusus.Aplikasi yang dikembangkan merupakan aplikasi yang memanfaatkan media suara manusia untuk diolah dengan komputasi komputer. Input suara manusia diolah dan dikomputasi dengan metode pitch shifting. Metode pitch shiftingmelakuan perubahaninputsuara manusia (frekuensi suara) dengan memanfaatkan pergeseran pitchsuara, sehingga output yang dihasilkan adalah suara manusia (frekuensi suara) yang berbeda tanpa mengubah kata yang diucapkan.

Meskipun tujuan kami membantu teknik Dubbing untuk film animasi, namun beberapa batasan di dalam penelitian ini masih tersedia dan kemungkinan masih dapat dikembangkan, diantaranya proses pengujian menggunakan sampel kata yang diucapkan tidak lebih dari 1 detik, skala pergeseran pitch dibatasi pada angka 0.5 sampai 2 , dan penelitian ini belum berjalan secara real-time.

Beberapa peneliti telah berhasil melakukan penelitian yang terkait dengan pengolahan suara manusia melalui komputasi teknologi informasi. Penelitian yang telah dilakukan oleh Dimple Garg, Sukhvinder Kaur, Dinesh Arora menjelaskan bahwa untuk proses pengenalan suara manusia ada beberapa parameter yang dimanfaatkan, yaitu cepstrum, pitch dan formant. Beberapa metode yang digunakan adalah Mel-Frequency Cepstrum Coefficient (MFCC) dan Linear Predictive Coding (LPC) (Kaur, 2014). Penelitian ini memfokuskan untuk mengenali suara manusia berdasarkan identitas suara masing-masing pembicara.

Penelitian selanjutnya yang dilakukan oleh Zulkarnain, Barmawi Andriana melakukan penelitian tentang komputasi suara yang memiliki tujuan akhir untuk mengenali suara 
manusia.Metode yang digunakan adalah LPC dengan parameter yang digunakan untuk mengenali suara manusia adalah formant (Zulkarnain, 2013).

Penelitian awal yang telah kami lakukan tentang sinyal suara hampir sama dengan penelitian lainnya. Penelitian kami juga fokus untuk mengenali suara manusia dengan parameter yang digunakan adalah cepstrum. Usulan kami melakukan modifikasi algoritma mel-frequency cepstrum coefficients (MFCC)di blok diagramnya untuk mempersingkat langkah kerja menghasilkan keluaran parameter cepstrum.Modifikasi yang dilakukan berkaitan dengan homomorphic, hal ini di dalamdigital signal processing (DSP) dikenal dengan perubahan struktur yang sama (Bhaskoro, 2013). Menurut Alan V. Oppenheim"Dalam sains dan teknik, homomorphic itu biasa digunakan untuk menemukan sinyal yang sulit untuk dipahami atau dianalisa dengan melakukan beberapa penyesuaian teknis penyelesaiannya. Strategi homomorphicmelakukan konversi sinyal menjadi linear pada sistem konvensional" (Oppenheim, 1992).

Penelitian yang dilakukan saat ini mencoba untuk menghasilkan keluaran parameter yang berbeda dari penelitian sebelumnya. Pada penelitian ini fokus terhadappitch dan timbre. Tujuan penelitian ini melakukan pencarian parameter pitchdan timbreuntuk merubah intonasi suara dari setiap manusia menjadi suara yang memiliki intonasi tinggi atau intonasi rendah diluar kemampuan dari manusia itu sendiri. Jenis suara yang dihasilkan ini mampu digunakan sebagai suara penyamaran dari sinyal suaraaseli yang dimiliki oleh setiap personal.

\section{DESAI N SISTEM}

Perancangan sistem yang di jadikan penelitian memiliki beberapa langkah di dalam penyelesaiannya. Beberapa langkah tersebut seperti pada Gambar 1:

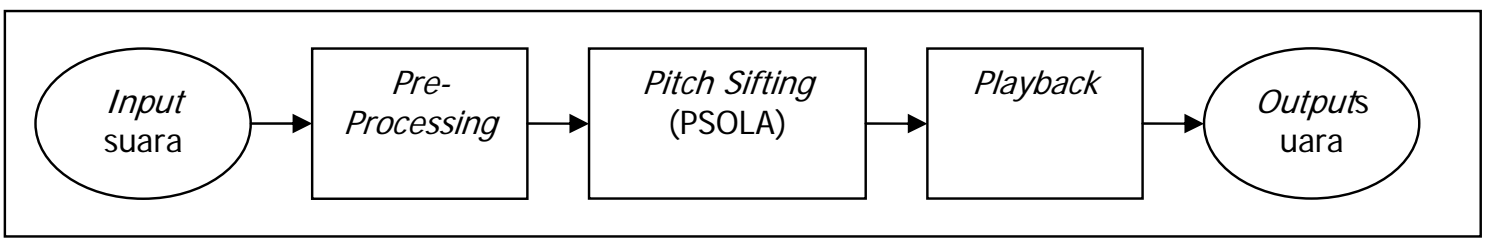

Gambar 1. Blok Diagram Pitch Shifting

Gambar 1 menjelaskan blok diagram menggunakan metode pitch shifting. Namun, sebelum menggunakan metode pitch shifting di Gambar 1 terlihat blok diagram yang menjelaskan tentang pre-processing. Kegiatanpre-processing tersebut penting untuk dilakukan karena sebagai normalisasi data suara yang akan diolah.

Pitch Shifting merupakan teknik yang digunakan untuk merubah pitch dari sinyal suara tanpa mempengaruhi durasi ataupun kecepatan dari sinyal suara tersebut. Kebalikan dari proses pitch shifting adalah time stretching yang digunakan untuk merubah durasi dan kecepatan sinyal suara tanpa merubah pitch. Selain menggunakan pitch shifting terdapat cara sederhana untuk merubah pitch, yaitu dengan melakukan resample pada sinyal suara namun cara ini juga mempengaruhi durasi dan kecepatan dari sinyal suara. 
Pitch Synchronous Overlapp Add (PSOLA) merupakan variasi dari algoritma SOLA (Shrawankar, 2011), digunakan untuk pemrosesan sinyal suara yang didasarkan pada pitch inputan suara. Algorithma PSOLA disusun dengan 2 tahap, tahap pertama disebut analysis phase dan tahap kedua disebut synthesis phase (Oppenheim, 1992), (Patton, 2014).

a. Analysis algorithm

1. Mencari dan menandai letak pitch period dari masukan sinyal suara. Fase ini disebut juga dengan pitch mark,

2. Membagi sinyal menjadi beberapa frame dimana tiap frame tadi terdapat pitch.

b. Synthesis algorithm

1. Memilih segmen atau frame yang memiliki data pitch mark;

2. Overlap and add segment yang dipilih.

\subsection{Pre-processing}

Pre-processing digunakan untuk menghasilkan sebuah sinyal keluaran suara yang memiliki nilai merata dalam jumlah sinyal yang sama. Proses ini dibagi menjadi beberapa proses didalamnya, yaitu: (i) sampling, (ii) frontend detection, (iii) normalisasi.

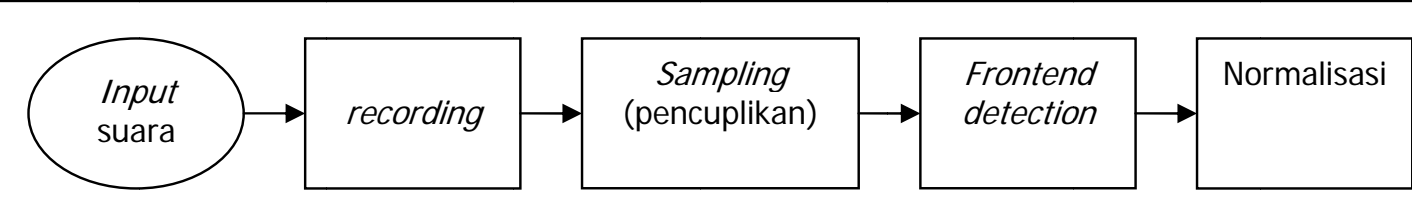

Gambar 2. Blok Diagram Pre-Processing

\subsubsection{Recording}

Perekaman suara dilakukan pada kecepatan $8000 \mathrm{~Hz}$ dengan resolusi (tingkat kuantisasi) 8 bit (1 byte) artinya dalam waktu satu detik didapatkan data sebanyak 8000 byte, channel stereo, lama merekam suara adalah 1 second dan disimpan dengan ekstensi .wav. Gambar 3 adalah properties hasil pengaturan suara.

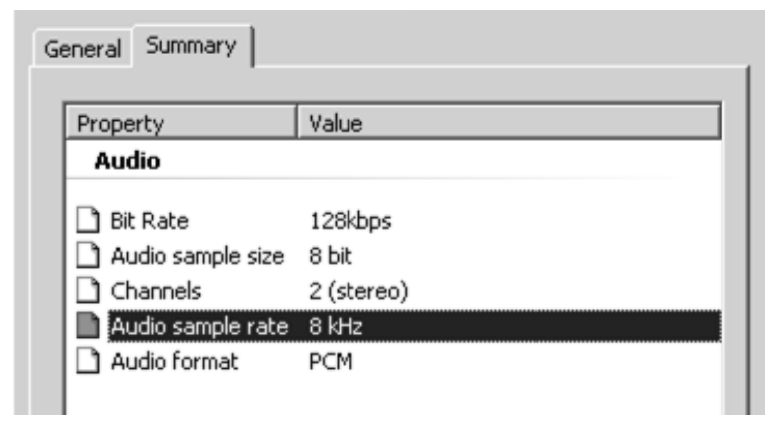

Gambar 3. Properties Perekaman Suara

Beberapa hal yang diperhatikan lainnya dalam perekaman suara diantaranya:(1) kondisi lingkungan yang minimnoise, (2) penggunaan perangkat yang sama,seperti penentuan peralatan microphone, soundcard, volume perekaman, frekuensi besar audio sampling, dan pelafalan atau pengucapan kata-kata, (3) pelafalan dengan intonasi normal (tidak terlalu cepat dan tidak terlalu lambat),(4) amplitudo (keras lemah) dengan intonasi normal (tidak 
terlalu tinggi dan tidak terlalu lemah).Gambar 4 adalah hasil gelombang suara dari proses perekaman suara.

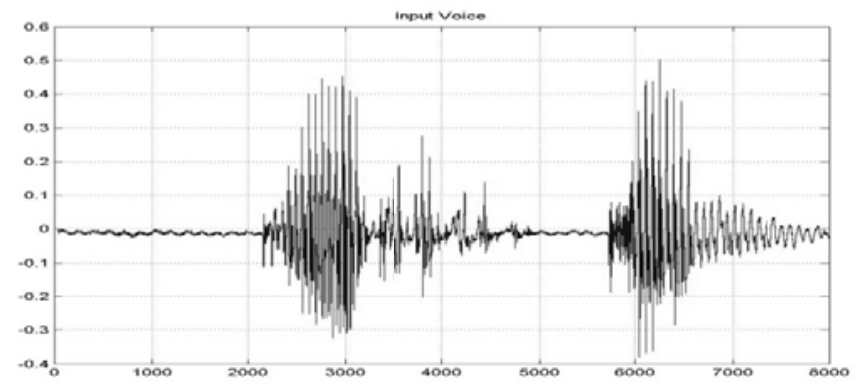

Gambar 4. Gelombang Sinyal Perekaman Suara

\subsubsection{Sampling}

Melakukan proses sampling karena membutuhkan proses pengambilandatasinyal kontinyu untuk setiap periode tertentu. Proses sampling sinyal menurut aturan nyquist adalah frekuensi sampling harus lebih besar dua kali dari frekuensi maksimum. Jika sinyal sampling tidak memenuhi syarat maka akan terjadi aliasing. Aliasing adalah suatu efek dimana sinyal yang dihasilkan memiliki frekuensi yang berbeda dari sinyal aslinya(Oppenheim, 1992). Persamaan kriteria nyquist adalah:

$$
f_{s} \geq 2 \times f \max
$$

Dimana:

$f_{\mathrm{s}} \quad=$ Frekuensi sinyal sampling

$f_{\max }=$ Frekuensi nilai maksimum sinyal informasi disampel

Kecepatan pencuplikan mengikuti pengaturan pada saat proses perekamansuara didasarkan dengan asumsi bahwa sinyal percakapan (speech) berada pada daerah frekuensi 300 $3400 \mathrm{~Hz}$. Semakin tinggi frekuensi sampling, maka semakin baik sinyal digita/yang dihasilkan. Sehingga, jika kecepatan sampling dan daerah frekuensi dimasukkan di persamaan nyquist maka akan memenuhi kriteria dari rumus tersebut.

$$
f_{s} \geq 2 \times f \text { max } \approx 8000 H z \geq(2 \times 3400 H z)
$$

Dimana:

$$
\begin{array}{ll}
f_{s} & =8000 \mathrm{~Hz} \\
f_{\max } & =3400 \mathrm{~Hz}(2 \times 3400 \mathrm{~Hz}=6800 \mathrm{~Hz})
\end{array}
$$

Gambar 5 adalah hasil sampling dengan jumlah data 16 dan 100: 

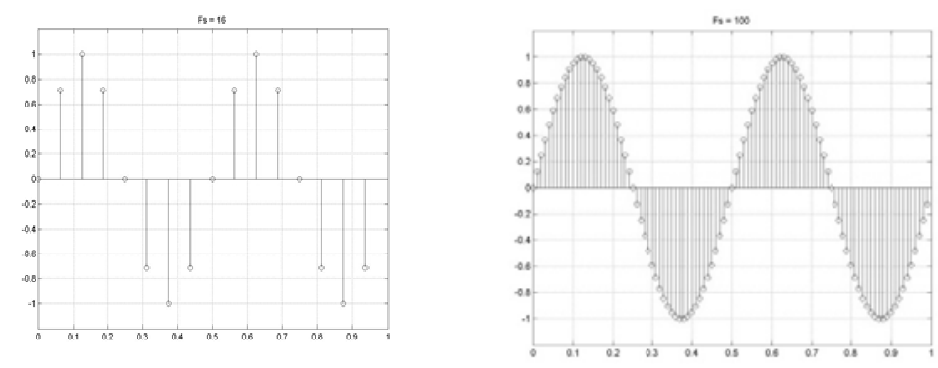

Gambar 5. Frekuensi Sampling

\subsubsection{Power}

Power atau energi menjadi salah satu bagian blok diagram yang dibutuhkan untuk menghasilkan proses frontend detection. Power dapat digunakan untuk melihat tinggi dan rendahnya sinyal suara yang dimasukkan atau dengan pengertian lainnya nilai yang dapat membedakan satu frame dengan lainnya. Hal ini dapat memudahkan untuk memisahkan sinyal voiced dan sinyal yang kosong (silent) atau noise. Gambar 6 adalah proses dari poweruntuk memperlihatkan letak voiced dan noise.

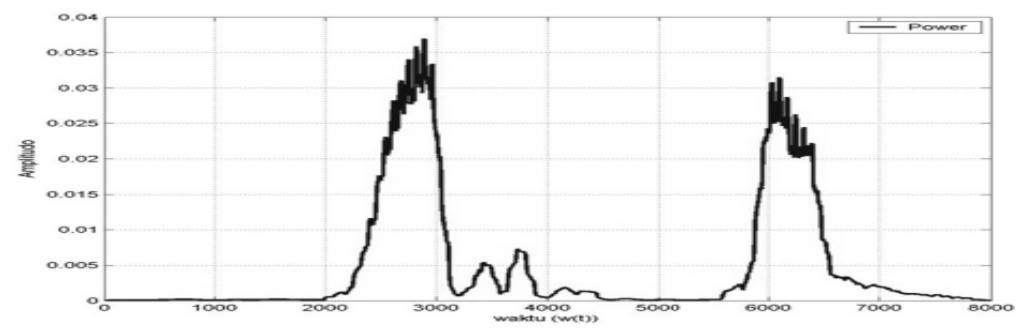

Gambar 6. Sinyal Power

Gambar 6 terlihat bahwa voiced terletak diantara data ke-2000 sampai data ke-7503. setelah diketahui dimana letak voiced dan dimana letak noise, maka dapat dilanjutkan ke langkah selanjutnya untuk mengambl nilai voiced-nya saja.

\subsubsection{Frontend Detection}

Frontend detection digunakan untuk mengambil data sinyal suara yang berisi voiced. Sehingga penggunaan frontenddetection ini untuk memisahkan sinyal noise dengan sinyal yang berisi data penting berupa ucapan tersebut. Biasanya dalam pengucapan terdapat sinyal silent (noise), pada awal dan akhir dari ucapan, untuk menghilangkan sinyal yang silent (noise) tersebut, maka penggunaan proses frontend detection sangat membantu.

Gambar 7adalahkategori suara voiced atau silent (noise). Unvoice adalah derah dimana vocal cord tidak berfungsi. Silence adalah daerah dimana sinyal bicara tidak diucapkan. Voiceadalah daerah dimana sinyal bicara diucapkan. 


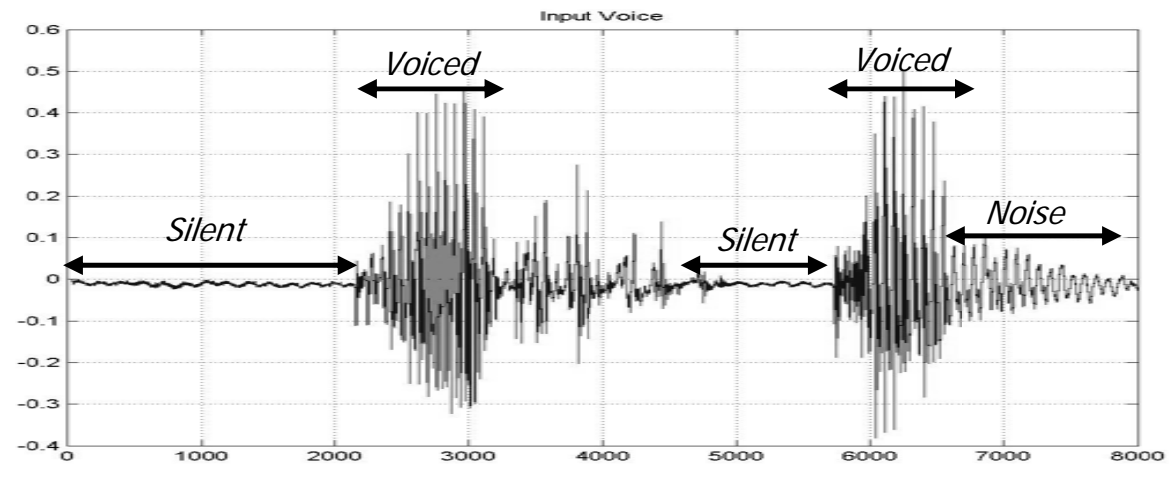

Gambar 7. Pembagian Sinyal Suara

Selanjutnya sinyal suara yang diambil adalah sinyal suara yang berkategori selain silent dan noise, karena sinyal selain silentdannoisetersebut terdapat nilai yang penting untuk dijadikan sebuah fitur suara, namun demikian sebelum mendapatkan sinyal voiced, terlebih dahulu harus menentukan batasan (threshold) dengan menggunakan hasil dari standard deviasi dan rata-rata pada proses sebelumnya. Hasil tersebut akan digunakan sebagai parameter untuk menentukan awal dan akhir dari suara, voicedakan memiliki nilai power yang melebihi nilai dari standar deviasi dan rata-rata dari voiced.

$$
\text { voiced } \geq R_{s}+S_{d}
$$

Dimana:

$R_{s} \quad=$ Rata-rata

$S_{d} \quad=$ Standar Deviasi

Berdasarkan rumus (3)didapatkan nilai awal dan akhir dari voiced. Gambar 8adalahthreshold dari voiced.

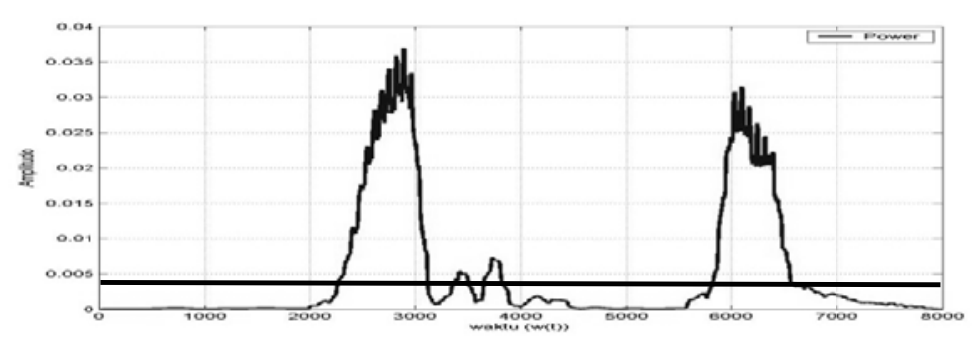

Gambar 8. Threshold Ucapan

Gambar 8terlihat bahwa sinyal voiced terletak pada data ke-2164 sampai data ke-7601. Berarti datake-0 sampai data ke-2163 dan data ke-7602 sampai data ke-8000 dihilangkan. Gambar 9 menampilkan bentuk sinyal frontend detection dan menampilkannya sesuai dengan nilai data yang hasilnya melebihi dari threshold yaitu dari data 2164 hingga 7601. 


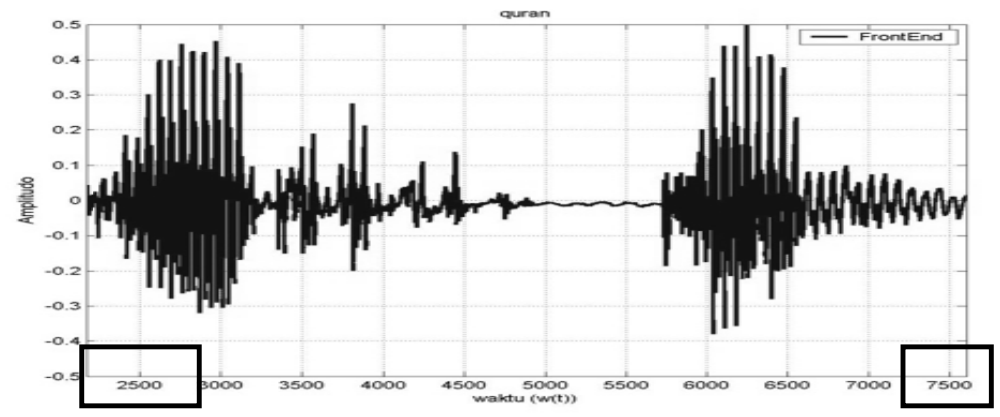

Gambar 9. Frontend Detection

\subsubsection{Normalisasi}

Normalisasi dilakukan untuk mengembalikan jumlah data yang hilang karena melewati proses frontend detection. Jumlah data harus dikembalikan ke-8000 karena untuk menyamakan dan memudahkan proses penghitungan dari pola kata yang diucapkan.Sebelumnya dapat dipahami bahwa proses frontend detection akan menghasilkan sinyal keluaran dengan nilai baru dari sebuah sinyal pola kata yang dimasukkan. Hasil jumlah datanya-pun berbeda-beda antara pola kata yang satu dengan lainnya, maka apabila hasil seperti ini tetap dibiarkan dan dilanjutkan kedalam proses perhitungan, maka akan menghasilkan perhitungan dengan jumlah frame yang berbeda-beda dan rumus yang berbeda pula untuk setiap sinyal masukan.

Normalisasi yang dilakukan disini terbagi menjadi dua bagian, diantaranya (i) normalisasi panjang data, normalisasi ini bertujuan untuk menambahkan jumlah data hingga mencapai jumlah yang sudah ditentukan. Cara kerjanya adalah, sinyal yang melalui proses frontend detection pada akhir nilainya ditambahkan beberapa data hingga mencapai panjang 8000 data.

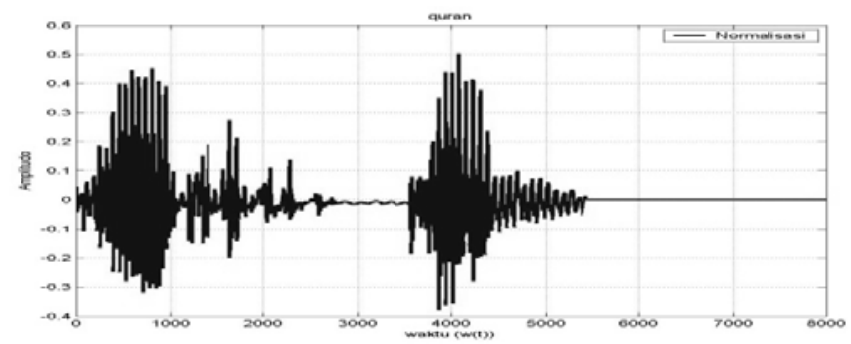

Gambar 10. Normalisasi Panjang Data

Selanjutnya, (ii) normalisasi amplitudo, normalisasi ini bertujuan untuk menyamakan jarak dekat atau jauhnya mulut dengan microphone pada saat pengucapan. Cara kerjanya adalah sinyal masukan diperiksa secara keseluruhan untuk mendapatkan nilai maksimumnya. Setelah mendapatkan nilai maksimumnya, maka setiap nilai dari sinyal tersebut dibagi dengan nilai maksimum dari sinyal tersebut. Sehingga disetiap sinyal ucapan yang dimasukkan memiliki tinggi amplitudo sebesar 1 untuk nilai maksimumnya. 


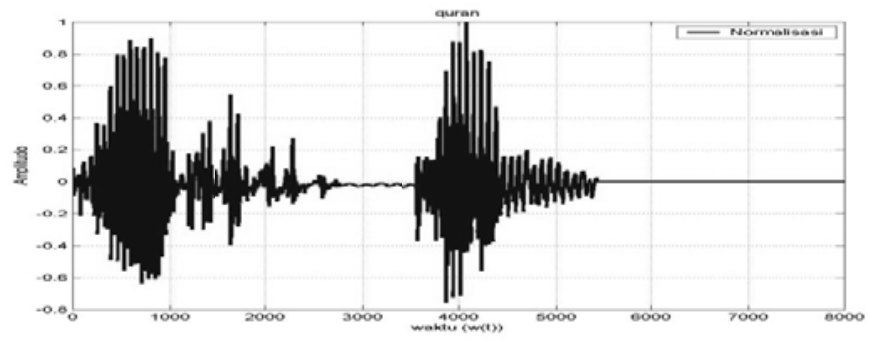

Gambar 11. Normalisasi Amplitudo

Setelah sinyal masukan melewati keseluruhan proses diatas, maka sinyal tersebut sudah siap untuk didapatkan fitur cirinya, fungsi keseluruhan preprocessing ini adalah untuk menghasilkan sebuah sinyal keluaran suara yang memiliki nilai merata dalam jumlah sinyal yang sama meskipun pola kata yang digunakan berbeda-beda, sehingga penghitungan dapat dilakukan dengan mudah.

\subsection{Pitch dan Timbre}

Secara umum terdapat 2 faktor yang berpengaruh membentuk ciri suara manusia yaitu pitch dan timbre (warna suara). Pitch berpengaruh terhadap frekuensi dasar (fundamental frequency) yang dimiliki oleh setiap benda yang bergetar dan mengeluarkan bunyi. Timbre merupakan muatan harmonik dari suara yang mempengaruhi karakteristik suara yang membuat kita bisa membedakan antara suara yang satu dengan yang lainnya (Naotoshi, 2008).

\subsubsection{Pitch}

Berbagai macam suara yang dapat didengar manusia merambat melalui udara dan dipantulkan ke segala arah. Salah satu parameter yang dapat digunakan untuk membedakan berbagai jenis suara adalah pitch atau frekuensi dasar dari suara tersebut. Perbedaan tinggi - rendah suara berhubungan dengan jarak antar pitch pada gelombang (pitch period). Panjang jarak tersebut berpengaruh pada frekuensi. Semakin pendek jarak (rapat) semakin tinggi frekuensi sebaliknya semakin lebar jarak semakin rendah frekuensi. Pada lingkup musik tinggi rendah suara diwakili dengan notasi. Setiap notasi memiliki standar frekuensi dan disimbolkan dengan angka atau huruf. Frekuensi sendiri merupakan banyaknya getaran per detik (misal: dari rapatan gelombang ke rapatan berikutnya) yang biasa dinyatakan dalam satuan $\mathrm{Hz}$.

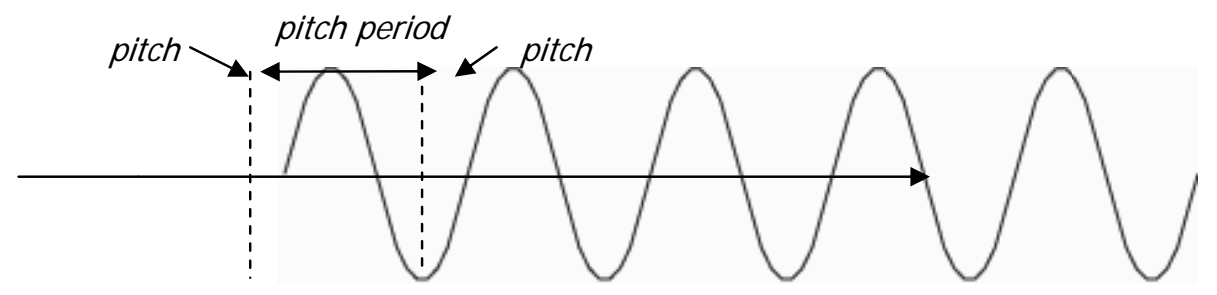

Gambar 12. Pitch dan Pitch Period

\subsubsection{Timbre}

Faktor lain yang menjadi ciri suara adalah timbre. Timbre dapat disebut sebagai kunci inti dari karakter suara manusia. Timbre merupakan faktor dari suara yang membuat kita bisa membedakan antara suara yang satu dengan yang lainnya, walaupun pitch dan level 
kekerasan (loudness, dipengaruhi oleh amplitudo) suaranya sama. Sebagai ilustrasi suara yang dihasilkan oleh gitar yang memainkan nada "A" berbeda dengan suara yang dihasilkan piano walaupun memainkan nada yang sama. Perbedaan karakter suara antara gitar dengan piano disebabkan perbedaan timbre. Getaran gelombang suara cukup kompleks, dan biasanya bergetar dalam beberapa frekuensi secara simultan. Inilah sebenarnya yang menyebabkan karakter suara masing-masing benda berbeda dikarenakan "muatan harmonik" timbreyang berbeda pula. Gambar 13 merupakan ilustrasi dari sebuah sinyal suara yang memiliki fundamental frekuensi sama dengan muatan harmonik berbeda.

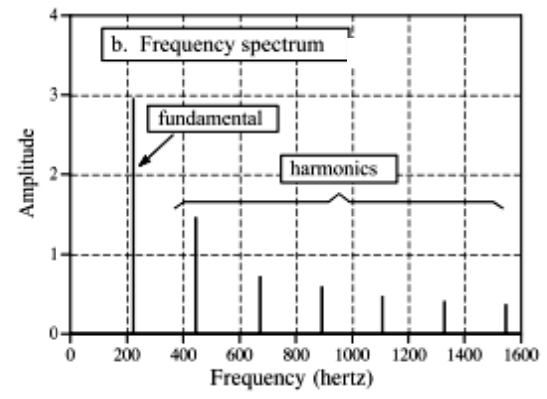

Gambar 13. Muatan Harmonik Pada Domain Frekuensi (Patton, 2014)

\subsection{Frame Blocking}

Frame Blocking(framming) adalah proses pembagian suara menjadi beberapa frame yang nantinya dapat memudahkan dalam perhitungan dan analisa suara, karena proses analisa akan berhasil dengan baik apabila sinyal yang dianalisa memiliki parameter yang tetap (berubah dengan lambat) terhadap waktu (time invariant). Framming dibuat sedemikian rupa sehingga sinyal suara dapat dianggap sebagai sinyal yang tidak berubah terhadap waktu.

Pada tahap ini, sinyal ucapan diblocking kedalam beberapa framedari keseluruhan sampel $\mathrm{N}$, dan dipisahkan dengan M sampel. Frameyang pertama terdiri dari $\mathrm{N}$ sampel sinyal pertama dan frame yang kedua dimulai $M$ sampel setelah $M$ sampel pertama dimulai (selalu overlap). Frameyang ketiga dimulai $2 \mathrm{M}$ sampel setelah M pertama ( $\mathrm{M}$ sampel dan frame yang kedua). Proses ini berlanjut sampai dengan keseluruhan sampel sinyal terhitung.

Satu frame terdiri dari beberapa sampel tergantung tiap berapa detik suara akan disampel dan berapa besar frekuensi samplingnya. Pengambilan sampel di penelitian ini dilakukan setiap $20 \mathrm{~ms}$, dan frekuensi sampling yang digunakan sebesar $8000 \mathrm{~Hz}$, sedangkan lama rekam selama 1 detik. Parameter yang sering digunakan adalah $\mathrm{N}$, untuk jumlah sampel pada analisis frame blocking dan $\mathrm{M}$, untuk jarak antara framesatudengan framelainnya.

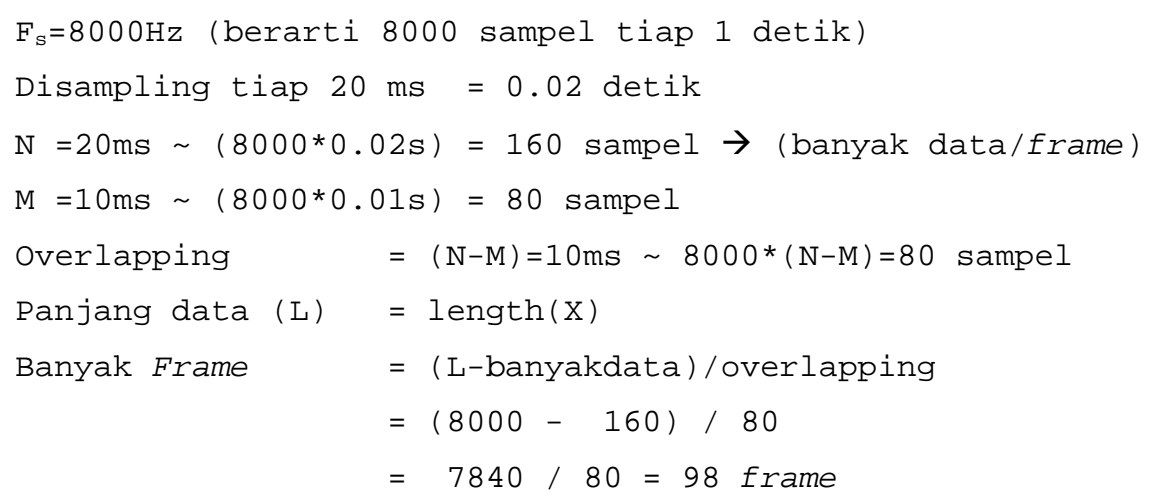


Mengikuti penghitungan diatas, maka setiap sinyal ucapan yang dimasukkan memiliki jumlah frame sebanyak 98 buah dan 160 data sampel per-frame-nya. Oleh karena itu kenapa proses preprocessing dibutuhkan, hal itu untuk menjawab dalam pemakaian rumus yang sudah ditentukan pada proses framming, sehingga sinyal yang dimasukkan akan menghasilkan jumlah frame yang sama.
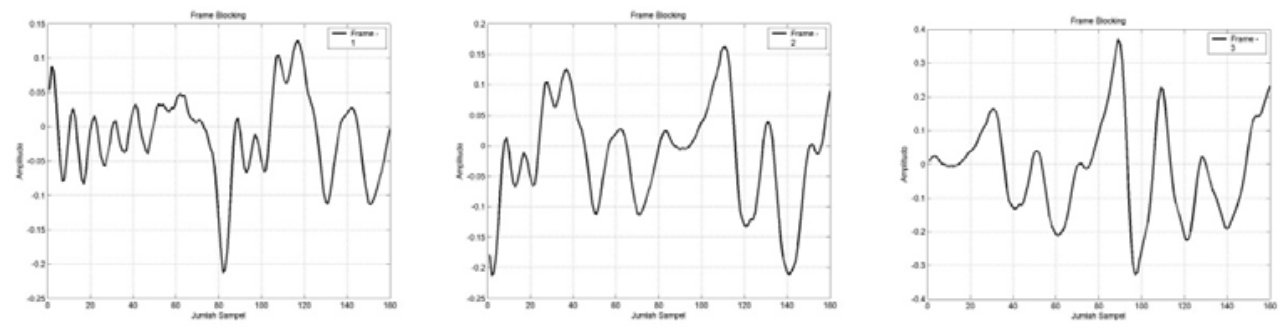

Gambar 14. Sinyal Framming

\subsection{Windowing}

Proses windowingadalah suatu proses weighting yang berfungsi untuk mengurangi efek diskontinuitas pada ujung-ujung frame yang dihasilkan oleh proses framming. Berikut adalah blok diagram dari sebuah proses windowing terhadap keluaran proses framming.Fungsi windowing yang digunakan pada penelitian ini adalah window hamming, yang mempunyai persamaan seperti berikut:

$$
w(n)=0.54-0.46 \cos \left(\frac{2 \times p h i \times n}{(n-1)}\right), 0 \leq n \leq(n-1)
$$

Nilai $(n)$ dalam windowing yang digunakan adalah sebanyak 160, karena sampel data pada setiap frameadalah 160 sampel. Berikut ini adalah nilai dan tampilan dari fungsi windowing dengan jumlah $(n)=160$.

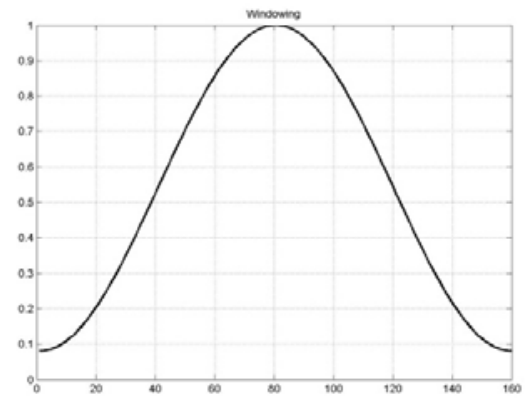

Gambar 15. Windowing $(n)=160$

Tiap frame sinyal hasil frame blocking dikalikan dengan fungsi window:

$$
x(n)=x_{i}(n) \times w(n), 0 \leq n \leq(n-1)
$$



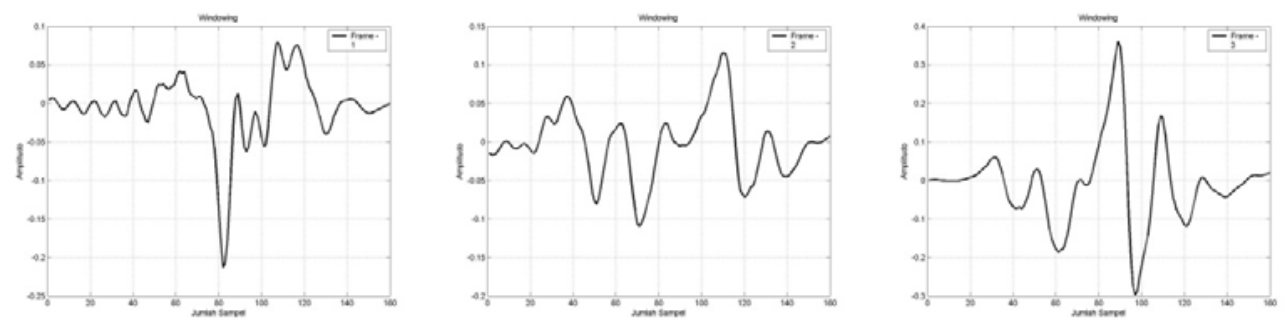

Gambar 16. Frame Windowing

\subsection{FFT}

Fast Fourier Transform (FFT)adalah suatu metode yang efisien untuk pengolahan sinyal, FFT ini digunakan untuk menyederhanakan komputasi data, dan hasil keluaran dari proses ini adalah sinyal spectrum. Penelitian ini digunakan FFT 256 titik karena data yang akan diproses sebanyak 160 buah data. Hasil sinyal yang di FFT merupakan suatu sinyal yang simetris atau menghasilkan bentuk pencerminan dari sisi sebelah kiri terhadap sisi sebelah kanannya, sehingga dari data sebanyak 256 data hanya diambil sebanyak 128. Gambar 17 adalahproses FFT.

$\begin{array}{ccc}\begin{array}{c}\text { Keluaran } \\ \text { Windowing } 160\end{array} & \text { FFT } & \text { Keluaran } \\ \text { data } & \text { FFT } & \text { FFT 128 data } \\ & \mathrm{N}=256 & \end{array}$

\section{Gambar 17. Proses FFT}

Frame sinyal hasil windowingakan melewati proses fungsi FFT. Sinyal yang dihasilkan proses ini akan sulit untuk dilihat dengan penglihatan, karena nilai hasil FFT terdapat nilai dalam bentuk imajiner, sehingga sulit untuk ditampilkan dalam bentuk gambar. Gambar 18 adalah bentuk imajiner dari FFT.
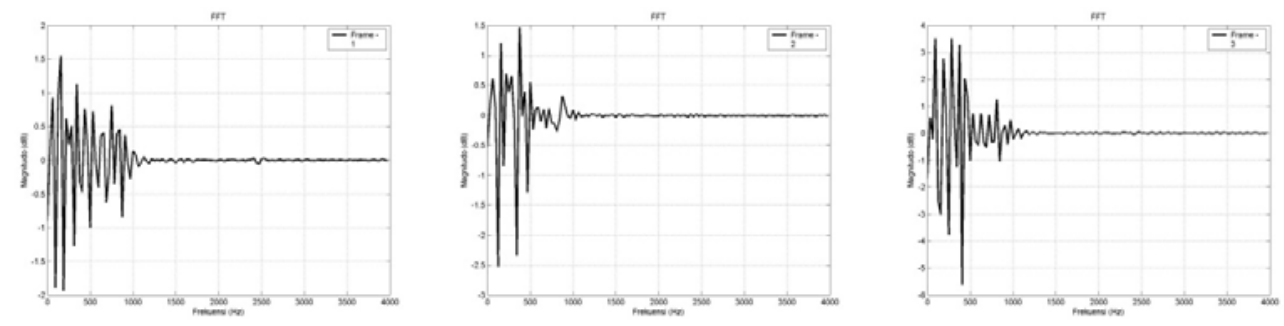

Gambar 18. Sinyal I majiner FFT

\subsection{Autocorrelation}

Autocorrelation merupakan cross-correlation dari suatu sinyal kepada sinyal itu sendiri. Pada pemrosesan sinyal cross-correlation merupakan metode pengukuran dari 2 gelombang sinyal sebagai fungsi jarak waktu antara 2 sinyal tersebut. Autocorrelationdapat digunakan untuk mendeteksi pitch (fundamental frekuensi) pada suatu sinyal periodic. 
Sebuah cara untuk mendeteksi pitch pada sinyal suara diperlukan suatu nilai autokorelasi. Nilai autokorelasi suatu sinyal suara akan menunjukkan bagaimana bentuk gelombang itu membentuk korelasi dengan diri sendiri sebagai fungsi perubahan waktu. Bentuk yang mirip (memiliki korelasi) pada setiap lag waktu tertentu menunjukkan perulangan bentuk (periodik) pola sinyal suara. Berdasarkan pola tersebut nantinya akan didapatkan nilai estimasi dari pitch (fundamental frekuensi).

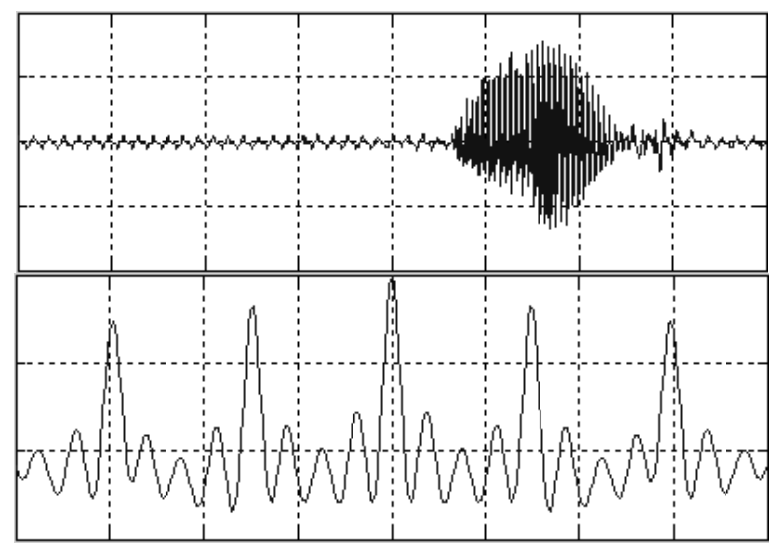

Gambar 19. Autokorelasi

\section{PENGUJ IAN}

Penggunaan sinyal sinus bertujuan memudahkan pengamatan terhadap hasil dari pitchshifting. Sinyal sinus lebih mudah diamati dari pada sinyal suara karena sinyal sinus selalu bersifat periodik terhadap domain waktu.Percobaan pertama akan dibangkitkan sinyal sinus dengan frekuensi sampling $8000 \mathrm{~Hz}$ durasi 1 detik dan frekuensi $100 \mathrm{~Hz}$. Setelah dibangkitkan data sinyal sinus akan disimpan dengan ekstensi .wav. Penggunaan ekstensi . wavdilakukan agar sinyal tersebut dapat digunakan untuk pengujian dengan suara. Selain itu, jika disimpan sebagai file suara, sinyal sinus tersebut akan lebih mudah digunakan kembali jika memang diperlukan.

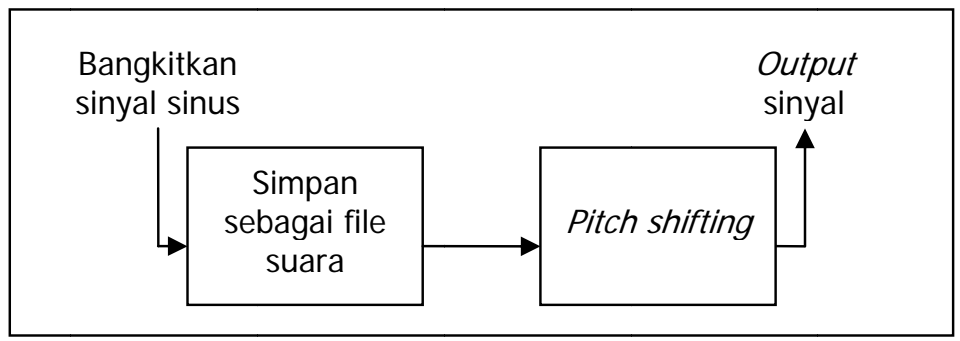

Gambar 20. Pengujian Aplikasi Menggunakan Sinyal Sinus

Gambar 20 menunjukan alur melakukan pitch shifting. Seperti yang sudah dijelaskan, hal yang pertama dilakukan adalah membangkitkan sinyal sinus dan menyimpannya dalam bentuk file suara. Sinyal tersebut kemudian dikomputasi dengan fungsi PSOLAdan kemudian menghasilkan output sinyal sinus baru yang pitch-nya sudah bergeser, atau dengan kata lain frekuensinya sudah berubah sesuai dengan skala yang ditentukan. 


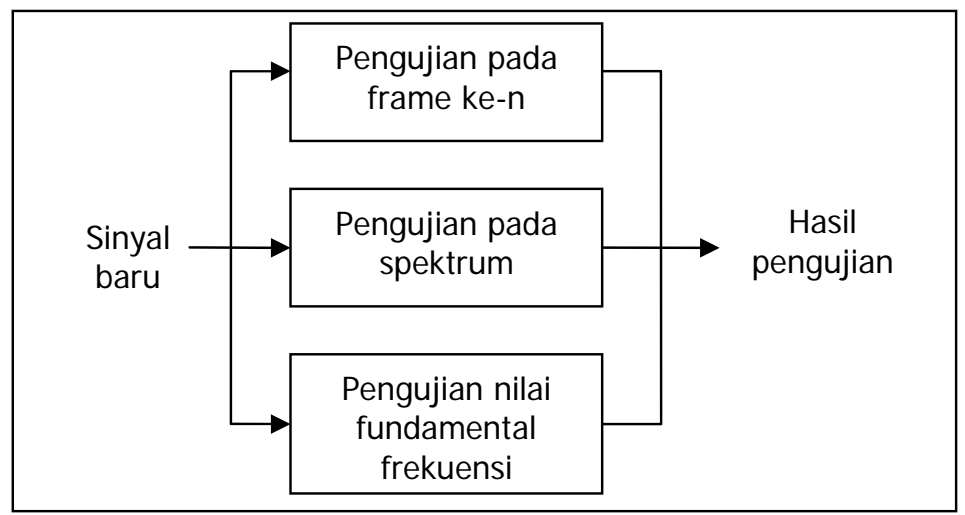

Gambar 21. Pengujian Sinyal Sinus

Pengujian hasil pitch shifting dari sinyal sinus dilakukan dengan 3 cara: (1) membandingkan bentuk sinyal input dengan sinyal output pada domain waktu. Pengamatan dilakukan pada frame tertentu yang sudah dilakukan. Dari pengamatan terhadap sinyal dapat dilihat pergeseran pitch; (2) membandingkan bentuk sinyal input dengan sinyal output pada domain frekuensi (spektrum). Dari pengamatan terhadap sinyal dapat dilihat pergeseran nilai frekuensi dasar pada domain frekuensi; (3) membandingkan nilai dari frekuensi dasar.

\subsection{Pembangkitan Sinyal Sinus}

Membangkitkan sinyal sinus yang dikembangkandengan tools matlab sebagai berikut:

$\mathrm{Fs}=8000$;

$\mathrm{t}=(1: 8000) / \mathrm{Fs}$;

$\mathrm{f}=100$;

$x=\sin \left(2^{*} p i^{*} f^{*} t\right)$;

wavwrite(x, Fs, 'sinfs8000f100.wav');

Bila dijalankan fungsi di atas akan membangkitkan sinyal sinus dengan frekuensi sampling $8000 \mathrm{~Hz}$ frekuensi $100 \mathrm{~Hz}$ dan durasi 1 detik. Setelah itu fungsi akan mengkonversi sinyal tersebut menjadi file suara dengan nama file 'sinfs8000f100.wav' .

\subsection{Pengujian Sinyal}

Menguji kinerja aplikasi, sinyal sinus yang akan diujikan akan di Shift Up dan Shift Down. Shift Up bertujuan untuk meningkatkan nilai frekuensi. Hasil dari Shift Up akan membuat jarak antar pitch semakin rapat dengan kata lain semakin tinggi frekuensi. Shift Down bertujuan untuk menurunkan nilai frekuensi. Hasil dari Shift Down akan membuat jarak antar pitch semakin lebar dengan kata lain semakin rendah frekuensi. Pengujian kali ini skala untuk Shift Up adalah 2 dan skala untuk Shift Downadalah 0.5.

\subsubsection{Shift Up}

Percobaan ini menggunakan menu offline. Langkah pertama yang dilakukan adalah memanggil file 'sinfs8000f100.wav' untuk kemudian dilakukan Shift Up. Isikan nilai skala dengan 2 dan tekan tombol PSOLA pada layar menu untuk memulai proses. 


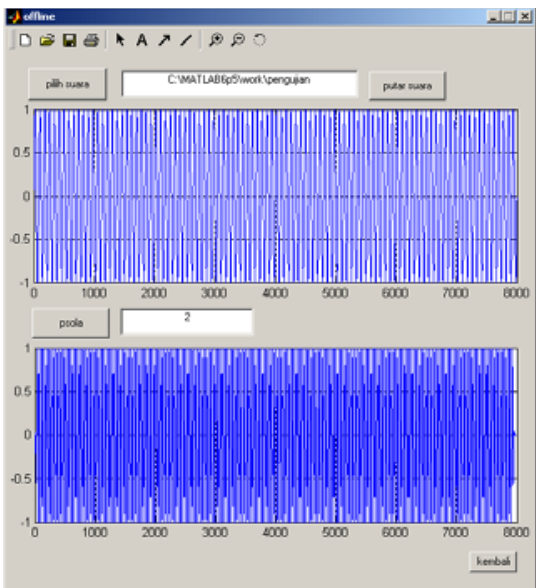

Gambar 22. Perubahan Sinyal Setelah Shift Up

Dari Percobaan di atas didapat sinyal hasil dari Shift Up dengan skala perubahan 2. jika dilihat dengan kasat mata sinyal output tampak lebih rapat dibanding sinyal awal. Untuk Melakukan pengujian lebih dalam sinyal akan diamati pada frame ke-n, domain frekuensi, dan dicari nilai fundamental frekuensinya.

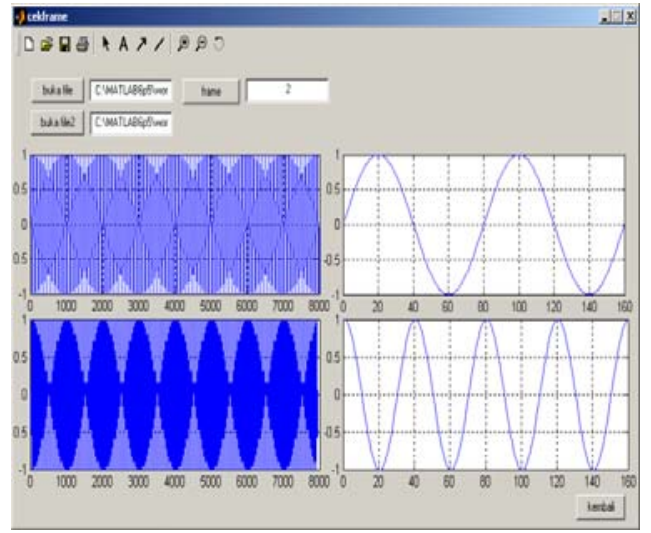

Gambar 23. Perubahan Sinyal Frame ke-2 Hasil Shift Up

Gambar 23adalah hasil pengamatan sinyal pada frame ke-2. Pada sinyal asal dapat dilihat bahwa pada frame tersebut terjadi 2 kali getaran, sedangkan pada sinyal hasil terjadi 4 kali getaran. Dari percobaan ini dapat dilihat bahwa pitch pada sinyal output telah berubah sehingga terjadi pergeseran pitch yang menyebabkan wavelengthberubah menjadi lebih pendek. Hal ini akan berdampak pada nilai frekuensi. Untuk melihat perubahan frekuensi, sinyal harus dilihat pada spektrumnya (domain frekuensi). 


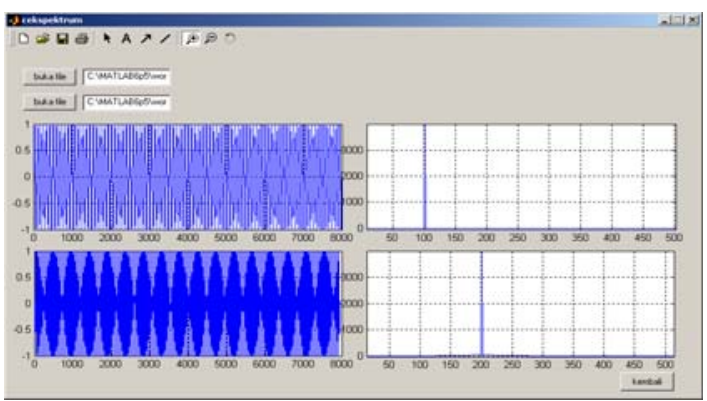

\section{Gambar 24. Pergeseran Nilai Frekuensi Hasil Shift Up}

Gambar 24adalah perbedaan frekuensi sinyal asal dan sinyal hasil. Pada sinyal awal menunjukkan bahwa frekuensi yang memiliki magnitude terbesar berada pada indek ke-100, sedangkan pada sinyal hasil menunjukkan bahwa frekuensi yang memiliki magnitude terbesar berada pada indek ke-200.

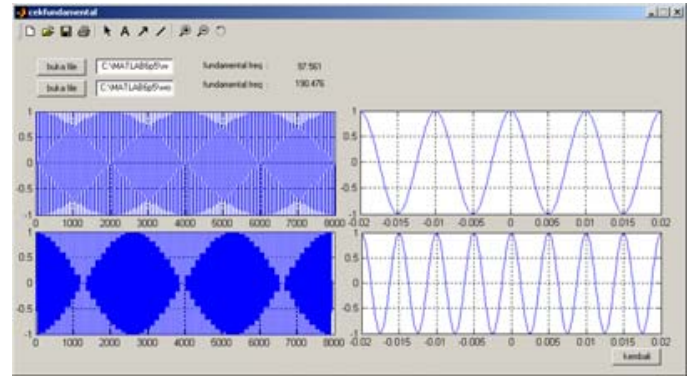

Gambar 25. Pencarian Nilai Fundamental Frekuensi

Percobaan terakhir menunjukkan nilai fundamental frekuensi dari sinyal awal adalah 97.561 dan untuk sinyal hasil 190.476.

\subsubsection{Shift Down}

Langkah yang dilakukan untuk percobaan ini sama dengan percobaan Shift Up, menggunakan menu offline. Langkah pertama yang dilakukan adalah memanggil file 'sinfs8000f100.wav' untuk kemudian dilakukan Shift Down. I sikan nilai skala dengan 0.5 dan tekan tombol PSOLA pada layar menu untuk memulai proses.

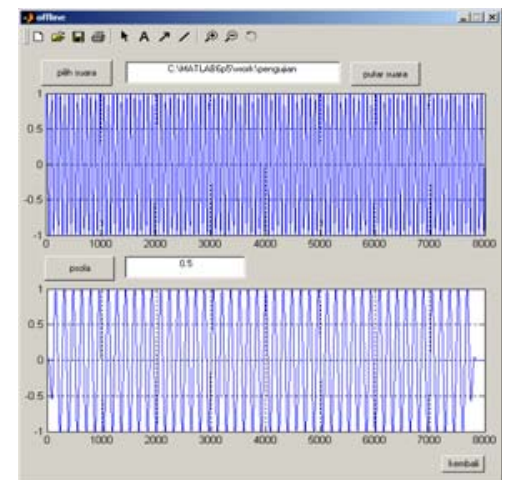

\section{Gambar 26. Perubahan Sinyal Setelah Shift Down}

Dari Percobaan di atas didapat sinyal hasil dari Shift Down dengan skala perubahan 0.5. jika dilihat dengan kasat mata sinyal output tampak lebih renggang dibanding sinyal awal. Untuk 
Melakukan pengujian lebih dalam sinyal akan diamati pada frame ke-n, domain frekuensi, dan dicari nilai fundamental frekuensinya.

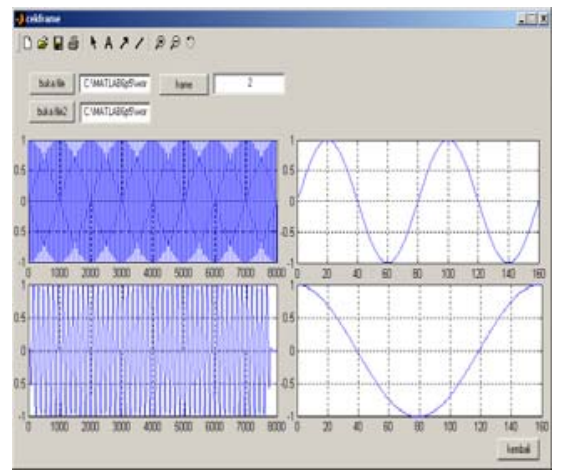

\section{Gambar 27. Perubahan Sinyal Hasil Shift Down}

Gambar 27adalah hasil pengamatan sinyal pada frame ke-2. Pada sinyal asal dapat dilihat bahwa pada frame tersebut terjadi 2 kali getaran, sedangkan pada sinyal hasil terjadi hanya 1 kali getaran. Dari percobaan ini dapat dilihat bahwa pitch pada sinyal output telah berubah sehingga terjadi pergeseran pitch yang menyebabkan wavelengthberubah menjadi lebih panjang. Hal ini akan berdampak pada nilai frekuensi. Untuk melihat perubahan frekuensi, sinyal harus dilihat pada spektrumnya (domain frekuensi).

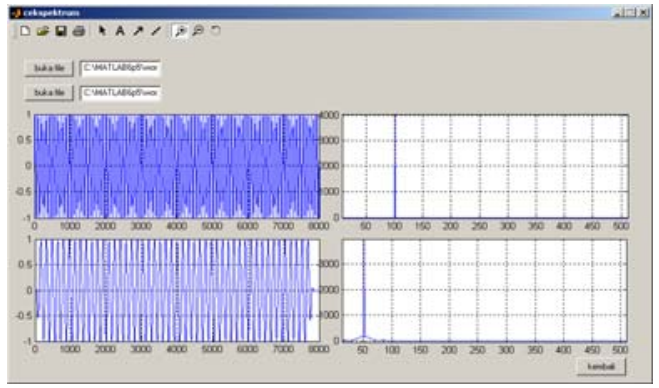

\section{Gambar 28. Pergeseran Nilai Frekuensi Hasil Shift Down}

Gambar 28 adalah perbedaan frekuensi sinyal asal dan sinyal hasil. Pada sinyal awal menunjukkan bahwa frekuensi yang memiliki magnitude terbesar berada pada indek 100, sedangkan pada sinyal hasil menunjukkan bahwa frekuensi yang memiliki magnitude terbesar berada pada indek 50 .

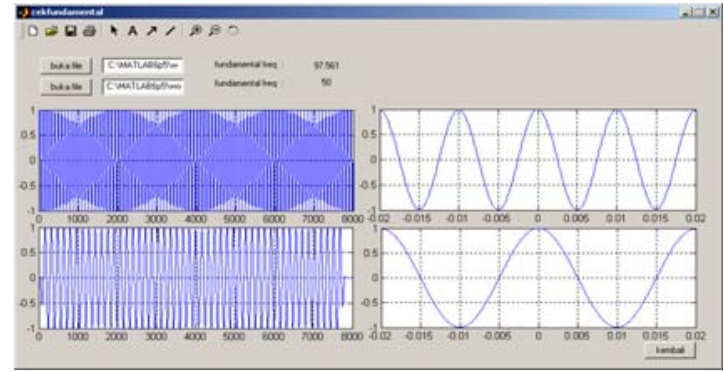

Gambar 29. Pencarian Nilai Fundamental Frekuensi 
Percobaan terakhir menunjukkan nilai fundamental frekuensi dari sinyal awal adalah 97.561 dan sinyal hasil adalah 50. Percobaan pengujian aplikasi terhadap sinyal sinus didapatkan tabel sebagai berikut:

Tabel 1. Pengujian Aplikasi Terhadap Sinyal Sinus

\begin{tabular}{|c|c|c|c|c|}
\hline skala & fundamental & $\begin{array}{c}\text { frekuensi } \\
\text { asal }\end{array}$ & $\begin{array}{c}\text { realisasi } \\
\text { perubahan skala }\end{array}$ & akurasi(\%) \\
\hline 2 & 190.476 & 97.561 & 1.952378512 & 97.61893 \\
\hline 1.5 & 145.455 & 97.561 & 1.490913377 & 99.39423 \\
\hline 1 & 97.561 & 97.561 & 1 & 100 \\
\hline 0.75 & 73.4 & 97.561 & 0.752349812 & 99.68767 \\
\hline 0.5 & 50 & 97.561 & 0.512499872 & 97.561 \\
\hline & & & rata - rata akurasi & 98.85236 \\
\hline
\end{tabular}

Tabel 1 berisi data hasil percobaan perubahan skala untuk pitch shifting dan efeknya terhadap perubahan frekuensi. Jika dilihat dari data tabel 1 , perubahan frekuensi relatif berbanding lurus dengan nilai dari skala perubahan yang ditentukan. Walaupun tidak benar $100 \%$ akurat (rata-rata nilai akurasi adalah 98\%) namun realisasi perubahan skala sudah mendekati nilai dari skala perubahan yang diinginkan. Dengan kata lain aplikasi berjalan sesuai dengan yang diinginkan pada percobaah dengan menggunakan sinyal sinus.

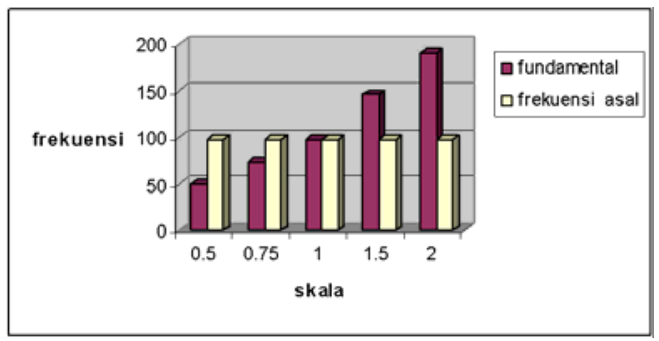

Gambar 30. Grafik Perubahan Nilai Fundamental Frekuensi Pada Pengujian Sinyal Sinus

\subsection{Pengujian Menggunakan Sinyal Suara}

Pengujian dengan sinyal suara akan memanfaatkan file suara dengan frekuensi sampling $8000 \mathrm{~Hz}$ dan durasi 1 detik. File suara yang diujikan berisi file pengucapan kata /halo/. Sama halnya dengan pengujian sinyal sinus, Pengujian hasil pitch shifting dari sinyal suara dilakukan dengan 3 cara: (1) membandingkan bentuk sinyal input dengan sinyal output pada domain waktu. Pengamatan dilakukan pada frame tertentu yang sudah dilakukan. Dari pengamatan terhadap sinyal dapat dilihat pergeseran pitch; (2) membandingkan bentuk sinyal input dengan sinyal output pada domain frekuensi (spektrum). Pengamatan terhadap sinyal dapat dilihat pergeseran nilai frekuensi dasar pada domain frekuensi; (3) membandingkan nilai dari frekuensi dasar.

\subsubsection{Pengujian Shift Up}

Langkah yang dilakukan untuk percobaan ini sama dengan percobaan Shift Up dan Shift Downpada sinyal sinus, menggunakan menu offline. Langkah pertama yang dilakukan adalah memanggil file 'halo.wav' untuk kemudian dilakukan Shift Down. I sikan nilai skala dengan 2 dan tekan tombol PSOLA pada layar menu untuk memulai proses. Hasil dari percobaan ini akan menampilkan perbedaan bentuk sinyal awal dengan sinyal hasil. Dengan skala perubahan 2 seharusnya bentuk sinyal hasil terlihat lebih rapat daripada bentuk sinyal asalnya. 


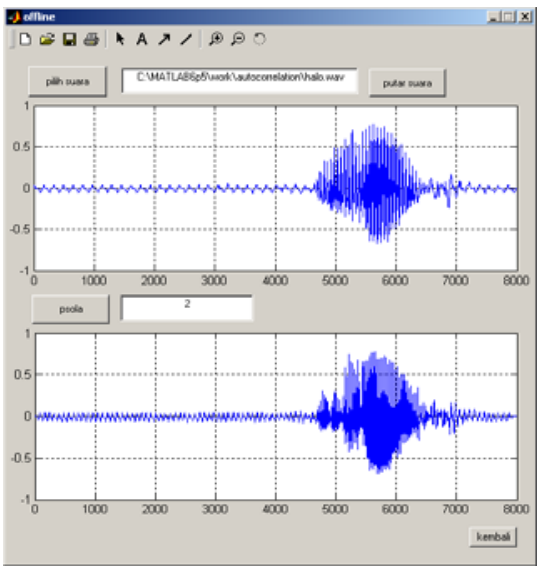

\section{Gambar 31. Percobaan Shift Up Pada Sinyal Suara}

Dari percobaan di atas didapat sinyal hasil dari Shift Up dengan skala perubahan 2. jika dilihat dengan kasat mata sinyal output tampak lebih rapat dibanding sinyal awal. Hal ini menunjukkan bahwa aplikasi telah berhasil mengubah pitch dari sinyal awal. Namun masih diperlukan lagi pengujian lebih lanjut untuk mengetahui tingkat akurasi aplikasi terhadap sinyal suara. Untuk Melakukan pengujian lebih dalam sinyal akan diamati pada frame ke-n, domain frekuensi, dan dicari nilai fundamental frekuensinya.

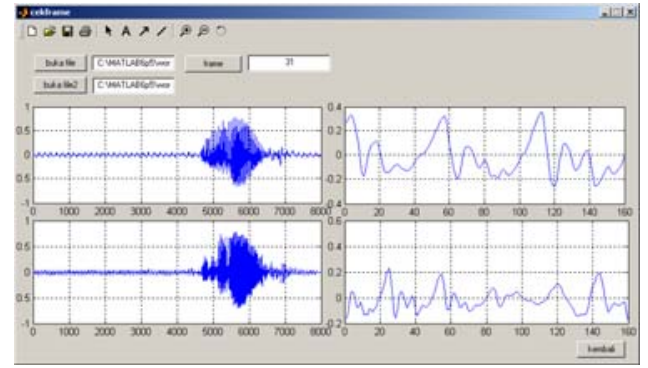

\section{Gambar 32. Perubahan Sinyal Frame Hasil Shift Up dengan Skala 2}

Gambar 31adalah hasil pengamatan sinyal pada frame ke-31. Jika dibandingkan dengan hasil pengujian pada sinyal sinus, pengamatan perubahan sinyal pada sinyal suara lebih sulit untuk dilihat. Pengujian pada sinyal sinus lebih mudah diamati karena sinyal sinus selalu periodik terhadap domain waktu.

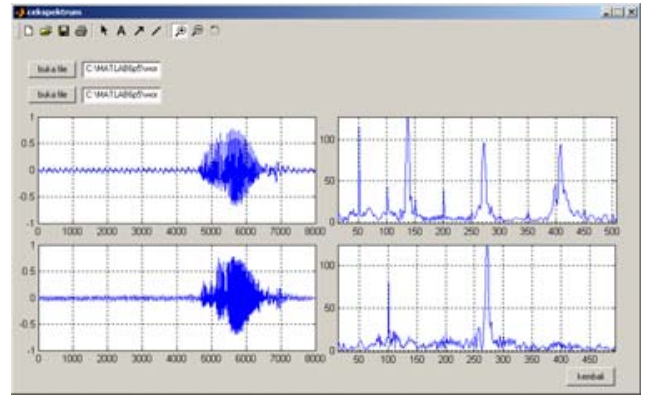

Gambar 33. Pergeseran Nilai Frekuensi Shift Updengan Skala 2 
Pada domain frekuensi perbedaan antara sinya asal dan sinyal hasil relatif lebih mudah diamati. Gambar di atas menunjukkan perbedaan frekuensi sinyal asal dan sinyal hasil. Pada sinyal awal menunjukkan bahwa frekuensi yang memiliki magnitude terbesar berada pada kisaran indek 130-140, sedangkan pada sinyal hasil menunjukkan bahwa frekuensi yang memiliki magnitude terbesar berada pada kisaran indek 260-280.

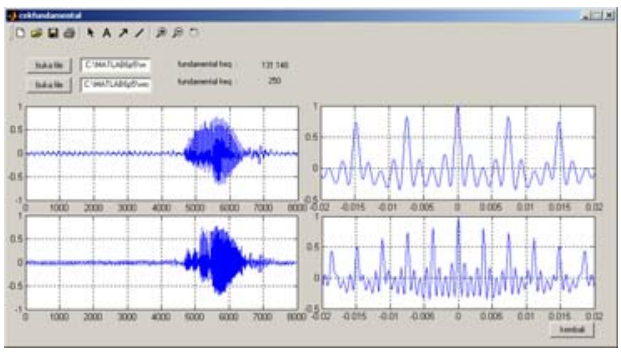

Gambar 34. Pencarian Nilai Fundamental Frekuensi

Percobaan terakhir menunjukkan nilai fundamental frekuensi dari sinyal awal diperkirakan berada pada nilai 131.148 dan untuk nilai fundamental frekuensi dari sinyal hasil diperkirakan berada pada nilai 250 .

\subsubsection{Pengujian Shift Down}

Langkah yang dilakukan untuk percobaan ini sama dengan percobaan Shift Up dan Shift Downpada sinyal sinus, menggunakan menu offline. Langkah pertama yang dilakukan adalah memanggil file 'halo.wav' untuk kemudian dilakukan Shift Down. Nilai di isikan dengan skala 0.5 .

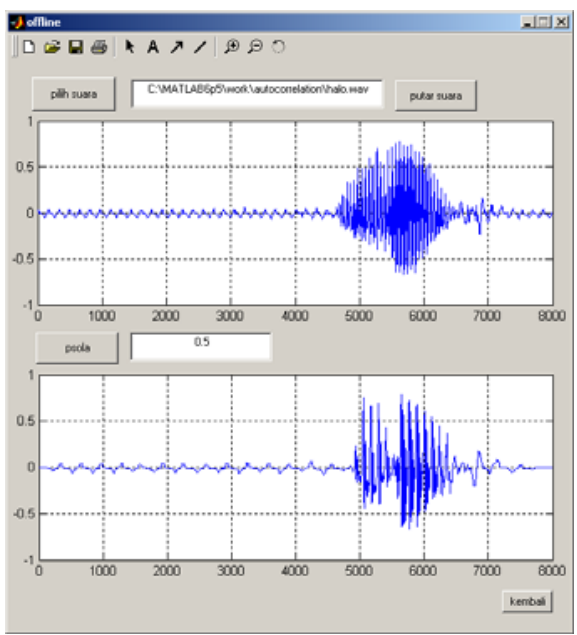

\section{Gambar 35. Percobaan Shift Down Sinyal Suara}

Percobaan di atas didapat sinyal hasil dari Shift Up dengan skala perubahan 0.5 . jika dilihat dengan kasat mata sinyal output tampak lebih renggang dibanding sinyal awal. Hal ini menunjukkan bahwa aplikasi telah berhasil mengubah pitch dari sinyal awal. Namun masih diperlukan lagi pengujian lebih lanjut untuk mengetahui tingkat akurasi aplikasi terhadap sinyal suara. Melakukan pengujian lebih dalam sinyal akan diamati pada frame ke-n, domain frekuensi, dan dicari nilai fundamental frekuensinya. 


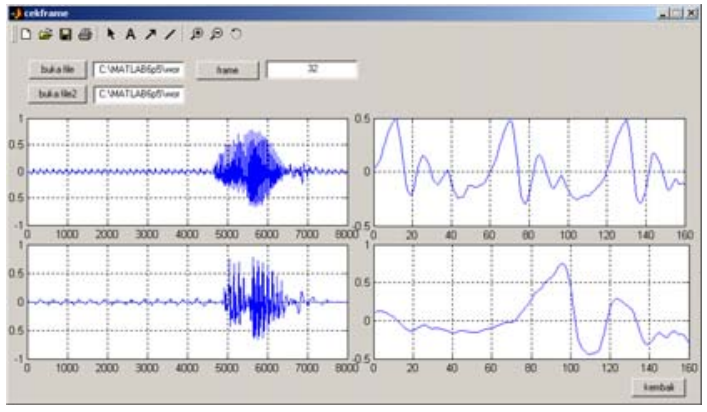

Gambar 36. Perubahan Sinyal Hasil Shift Down Skala 0.5

Gambar 35 adalah hasil pengamatan sinyal pada frame ke-31. Jika dibandingkan dengan hasil pengujian pada sinyal sinus, pengamatan perubahan sinyal pada sinyal suara lebih sulit untuk dilihat. Pengujian pada sinyal sinus lebih mudah diamati karena sinyal sinus selalu periodik terhadap domain waktu.

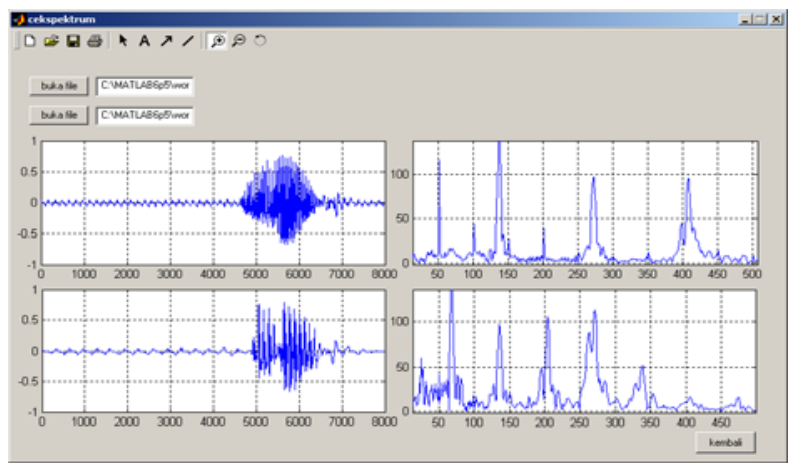

\section{Gambar 37. Pergeseran Nilai Frekuensi Shift Down Skala 0.5}

Pada domain frekuensi perbedaan antara sinya asal dan sinyal hasil relatif lebih mudah diamati. Gambar di atas menunjukkan perbedaan frekuensi sinyal asal dan sinyal hasil. Pada sinyal awal menunjukkan bahwa frekuensi yang memiliki magnitude terbesar berada pada kisaran indek 130-140, sedangkan pada sinyal hasil menunjukkan bahwa frekuensi yang memiliki magnitude terbesar berada pada kisaran indek 60-70.

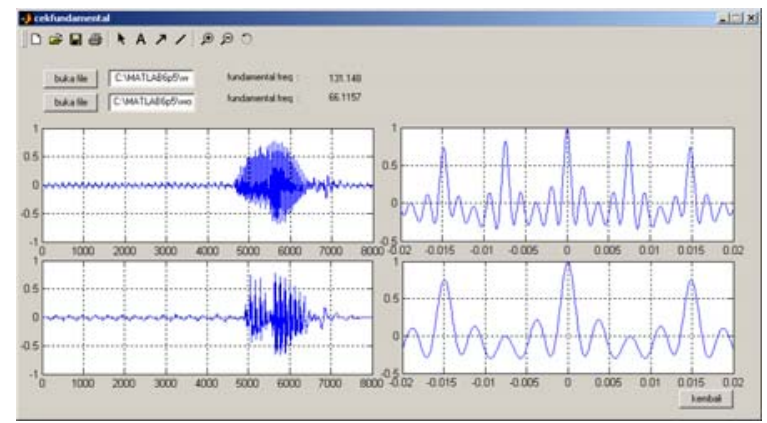

Gambar 38. Pencarian Nilai Fundamental Frekuensi

Percobaan terakhir menunjukkan nilai fundamental frekuensi dari sinyal awal diperkirakan berada pada nilai 131.148 dan untuk nilai fundamental frekuensi dari sinyal hasil diperkirakan berada pada nilai 66.1157. 
Percobaan di atas didapatkan data - data yang akan menunjang proses analisa kinerja dari aplikasi. Data tersebut kemudian akan ditabulasi dan dikelompokkan berdasarkan pengujian pada sinyal sinus dan pada sinyal suara. Analisa ditekankan pada akurasi pengaruh skala pergeseran pitch terhadap fundamental frekuensi. Berikut rumus penghitungan akurasi.

$$
\text { realisasi skala }=\frac{f_{\text {ooutput }}}{f_{\text {oinput }}} \text {, akurasi }=\frac{\text { realisasi_skala }}{\text { input_skala }} \times 100 \%(6)
$$

dimana

$$
f_{0} \quad=\text { fundamental frekuensi }
$$

Percobaan pengujian aplikasi terhadap sinyal suara didapatkan 5 tabel data pengujian sinyal suara "halo", "selamat pagi", "apa kabar", "baik sekali", dan "sampai jumpa". Tabel 2 hasil pengujian terhadap sinyal suara ucapan halo.

\begin{tabular}{|c|c|c|c|c|}
\hline skala & fundamental & $\begin{array}{c}\text { frekuensi } \\
\text { asal }\end{array}$ & $\begin{array}{c}\text { realisasi } \\
\text { Perubahan skala }\end{array}$ & akurasi $(\%)$ \\
\hline 2 & 250 & 131.148 & 1.906243328 & 95.31217 \\
\hline 1.5 & 190.476 & 131.148 & 1.452374417 & 96.82496 \\
\hline 1 & 131.148 & 131.148 & 1 & 100 \\
\hline 0.75 & 98.77 & 131.148 & 0.753118614 & 99.58591 \\
\hline 0.5 & 66.1157 & 131.148 & 0.504130448 & 99.18068 \\
\hline & & & rata-rata akurasi & 98.18074 \\
\hline
\end{tabular}

Tabel 2. Pengujian Aplikasi Terhadap Sinyal Suara Ucapan “Halo”

Percobaan tabel 2, hasil yang ditampilkan tidak jauh berbeda dengan hasil dari percobaan pitch shifting terhadap sinyal sinus. Perubahan frekuensi relatif berbanding lurus dengan nilai dari skala perubahan yang ditentukan. Hal ini menunjukkan bahwa aplikasi yang dibangun berhasil melakukan perubahan pitch sesuai dengan skala yang ditentukan (rata-rata akurasi 98\%). Semakin tinggi nilai skala pergeseran semakin besar pula nilai frekuensi dasar, sebaliknya semakin rendah nilai pergeseran semakin rendah pula nilai frekuensi dasar.

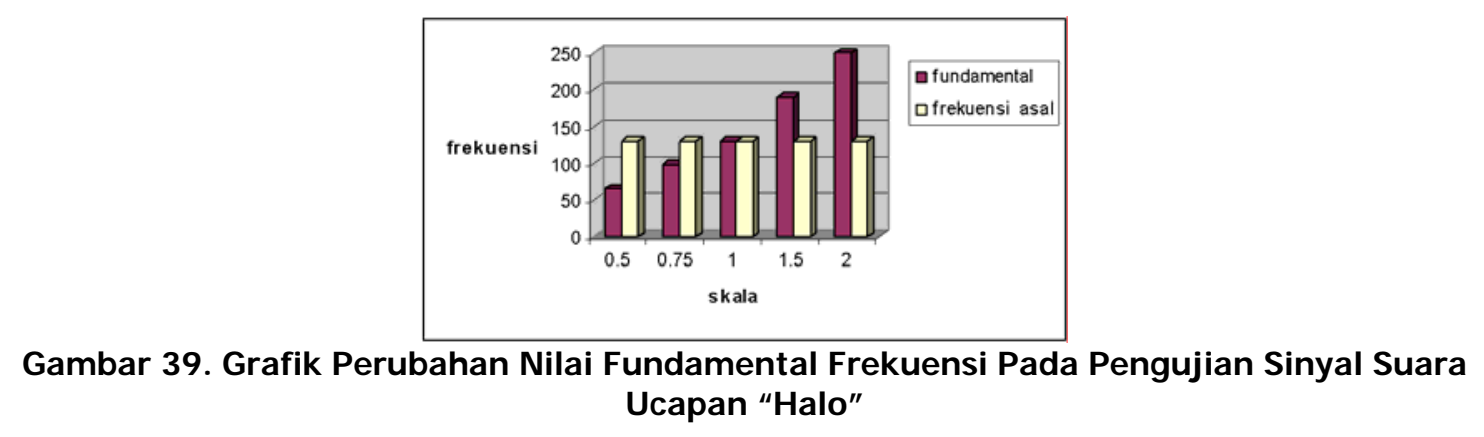

\section{KESI MPULAN}

Perubahan sinyal sinus frekuensi relatif berbanding lurus dengan nilai dari skala perubahan yang ditentukan. Walaupun tidak benar-benar akurat (rata -rata akurasi 98\%) namun realisasi perubahan skala sudah mendekati nilai dari skala perubahan yang diinginkan,dengan kata lain aplikasi berjalan sesuai dengan yang diinginkan pada percobaan dengan menggunakan sinyal sinus. Sedangkan perubahan sinyal suara frekuensi relatif berbanding lurus dengan nilai dari skala perubahan yang ditentukan. Hal ini menunjukkan bahwa aplikasi yang dibangun berhasil melakukan perubahan pitch sesuai dengan skala yang 
ditentukan (rata-rata akurasi 98\%). Semakin tinggi nilai skala pergeseran semakin besar pula nilai frekuensi dasar, sebaliknya semakin rendah nilai pergeseran semakin rendah pula nilai frekuensi dasar.

\section{DAFTAR RUJ UKAN}

Bhaskoro, Susetyo Bagas. (2013).Cepstrum Parameter for Human Voice Recognition, Engineering International Conference, Semarang, pp. II115-II119.

Patton, Joshua.(2014).Pitch_Synchronous_Overlap-Add. Dipetik 1 November 2014, dari http://www.researchgate. nēt/publication/242507840_ELEC_484_Project_-

Pitch Synchronous_Overlap-Add

Kaur, Sukhvinder, Dinesh Arora Dimple Garg. (2012).Comparative Analysis of Speech Processing Techniques for Gender Recognition, International Journal of Advances in Electrical and Electronics Engineering, pp. 278-283.

Zulkarnain, Barmawi Andriana. (2013).Speech Recognition System Based on Linear Predictive Coding (LPC) and Hidden Markov Model (HMM) using Matlab for Speaker Identification, Engineering International Conference, Semarang, pp. II82-II86.

Shrawankar, Urmila, Rashmi Makhijani. (2011).Speech Enhancement Using Pitch Detection Approach For Noisy, International Journal Of Engineering Science And Technology (IJEST), vol. 3, no. 2.

Naotoshi, Seo sonots. (2008).Pitch Detection. Dipetik 20 November 2014,dari ENEE632 Project 4 Part l: Pitch Detection. http://note.sonots.com/?plugin=attach\&refer=SciSoftware\% 2FPitch\&openfile=pitch. $p d f$

John G, Dimitris G. Manolakis. Proakis. (1992).Digital Signal Processing Principles, Algorithms, and Applications. New York, US: McMillan. 